ECONOMIC CONSEQUENCES OF HIRING AN AUDITOR WITH INDUSTRY

EXPERTISE: AN EMPIRICAL ANALYSIS AMONG NPOS

\author{
Anne-Mie Reheul (KU Leuven) \\ anne-mie.reheul@kuleuven.be \\ Tom Van Caneghem (KU Leuven, Universiteit Antwerpen) * \\ tom.vancaneghem@kuleuven.be \\ Machteld Van den Bogaerd (KU Leuven) \\ machteld.vandenbogaerd@kuleuven.be \\ Sandra Verbruggen (KU Leuven) \\ sandra.verbruggen@kuleuven.be \\ Warmoesberg 26 \\ 1000 Brussel
}

* corresponding author 
Anne-Mie Reheul is assistant professor at the Faculty of Economics and Business of KU Leuven. Her research focuses on small business, nonprofit, management accounting and external auditing. She has publications in Nonprofit and Voluntary Sector Quarterly; Voluntas; Journal of Public Budgeting, Accounting and Financial Management; and International Journal of Auditing, among others.

Tom Van Caneghem is associate professor at the Faculty of Economics and Business of KU Leuven. His research focuses on financial reporting and external auditing (with an emphasis on NPOs and SMEs). He has publications in Nonprofit and Voluntary Sector Quarterly; Auditing: A Journal of Practice \& Theory; European Accounting Review; Small Business Economics and International Small Business Journal, among others.

Machteld Van den Bogaerd is assistant professor at the Faculty of Economics and Business of the KU Leuven. Her research interests are corporate reputation, media reputation, nonprofit and data sciences. She published in Expert Systems with Applications, Corporate Reputation Review en European Management Journal.

Sandra Verbruggen is assistant professor at the Faculty of Economics and Business of the KU Leuven. Her research focuses on nonprofit accounting and governance as well as external auditing. She has publications in Nonprofit and Voluntary Sector Quarterly, Voluntas and International Journal of Auditing, among others. 


\title{
ECONOMIC CONSEQUENCES OF HIRING AN AUDITOR WITH INDUSTRY EXPERTISE: AN EMPIRICAL ANALYSIS AMONG NPOS
}

\begin{abstract}
This study examines economic consequences of auditor choice in the Belgian nonprofit (NP) setting, where the identity of both the audit firm and the audit partner is required to be disclosed. Specifically, we examine the influence of auditor choice in favor of an auditor with industry expertise on future contributions (being the sum of donations and grants) received among a large sample of Belgian nonprofit organizations (NPOs). Consistent with a signaling perspective, our results indicate that NPOs benefit from engaging an audit partner with industry expertise, by positively influencing future contributions received by the NPO. However, we observe no significant effect of audit firm industry expertise on future contributions received. Our results therefore suggest that NPOs' resource providers presume that industry expertise is situated at the signing partner level, rather than at the audit firm level.
\end{abstract}

Keywords: auditor choice, nonprofit organization, contribution, financial reporting, auditor industry expertise 


\section{Introduction}

Non-profit organizations (NPOs) typically rely heavily on government grants, donations and volunteers and enjoy a variety of tax benefits. NPOs are therefore accountable to the general public, who are, in fact, financing these donations, grants, and fiscal benefits. In the recent past, there has been an international trend to increase financial disclosure regulation for NPOs in order to improve their public accountability. Even though financial reporting does not report on the effect of NPOs' strategies and programs for beneficiaries (Torres and Pina, 2003), it does allow assessing NPOs' financial position as well as the sources and uses of NPOs' funds. Prior research demonstrated that financial statement (FS) quality among NPOs is worrisome, however. NPOs are found to manage their earnings (Leone and Van Horn, 2005; Eldenburg et al., 2011; Verbruggen and Christiaens, 2012; Jegers, 2013), to misreport expenses (e.g., Jones and Roberts, 2006) and to make violations against GAAP (Verbruggen et al., 2011a). Non-profit (NP) managers misreport due to a lack of expertise (Burks, 2015), but also because it may give rise to economic benefits, including access to funding (Jegers, 2013; Vermeer et al., 2014). According to Vermeer et al. (2014) and Burks (2015) accounting errors and aggressiveness are a bigger problem in NPOs than in similar-sized for-profits. Therefore, the trend in many countries has been not only to require disclosure of FS but to have them monitored by an external auditor, and many NPOs are voluntarily embracing use of external auditors to enhance their credibility (e.g., Abraham, 1999; Privett and Erhun, 2011).

As argued by Kitching (2009), the external FS audit plays an important role in the NP sector because the information asymmetry between the resource providers and the organization is typically greater than in the for-profit sector. Whereas the business environment of publicly traded for-profits is characterized by various information intermediaries (e.g., financial 
analysts, financial press, etc.), these sources of information (such as earnings forecasts, market values, etc.) are unavailable to resource providers in a NP setting (Harris and Krishnan, 2012). In addition, resource providers do not receive direct benefit from the contributions they provide to a NPO and, therefore, cannot directly see whether the funds were used in line with their intentions (Tate, 2007). An external FS audit results in FS being more credible and becoming a more effective mechanism in monitoring NPO behavior and performance (Carey et al., 2013). As reported by Krishnan et al. (2006) and Keating et al. (2008), the use of an external auditor reduces the probability that NPOs will misreport. Not surprisingly, various studies demonstrate that donors and governments analyze NPOs' FS (e.g., efficiency ratios) (e.g., Thornton and Belski, 2010; Harris et al., 2015) and the judgment of an external auditor (e.g., Petrovits et al., 2011; Verbruggen et al., 2011b; Feng, 2014; Amin and Harris, 2015) before making contributions.

In the literature, it is generally acknowledged that auditors are (perceived to be) quality differentiated (cf. Literature review and hypothesis development). Accordingly, one mechanism that managers can use to provide a signal on the credibility of financial reporting is auditor choice (Titman and Trueman, 1986; Datar et al., 1991). Drawing on a signaling perspective, we examine whether hiring an auditor with industry expertise has a positive effect on future contributions received by the NPO. Our study is focused on Belgium, which like other countries has followed the trend of requiring NPOs (meeting certain size thresholds (see infra)) to disclose FS and have them monitored by an external auditor. Contributions received by Belgian NPOs mainly consist of government grants (e.g., Jegers, 2011; Verbruggen and Christiaens, 2012). Because Belgian subsidizing and supervisory governments could be considered professional users of NPOs' FS, the Belgian setting provides a relevant setting to explore the issue under study. That is, unlike small donors, governments are better able to assess auditors' industry expertise (and thus the signal of hiring 
an auditor with industry expertise). This study has relevance for other settings as well. In the US, UK, Canada, Australia and many parts of Europe, NPOs (depending on subsector) rely heavily on government grants (e.g., Haggar-Guenette et al., 2009; Wren, 2009; Pettijohn et al., 2013).

The main contributions of the current paper are twofold. First, our study adds to the very scarce literature on the economic consequences of auditor choice in the NP arena. While the economic consequences of auditor choice have received considerable attention in the forprofit setting (e.g., Teoh and Wong, 1993; Balsam et al., 2003), only limited research has been conducted in the NP arena. The nonprofit studies that did assess economic consequences of auditor reputation (Kitching, 2009; Harris and Krishnan, 2012) employed the BigN proxy, however. Because prior research questions the validity of the BigN proxy in a NP context (cf. infra), we rely on auditor industry expertise as an alternative auditor reputation proxy. Second, we add to the literature by assessing economic consequences of industry expertise at both the signing partner and audit firm level. Chi and Chin (2011) revealed in a for profit setting that industry expertise at the signing partner level is more relevant than at the audit firm level in explaining financial reporting consequences (such as discretionary accruals and audit modifications, capturing actual audit quality). We will investigate in a nonprofit context (i) whether industry expertise explains economic consequences (namely future contributions received) because of the perception or signal of audit quality; and (ii) which level of industry expertise (partner level vs. audit firm level) is more relevant in explaining it. Public disclosure of the name of the signing partner as well as the audit firm in Belgium ${ }^{1}$ provides us with a unique opportunity to empirically verify whether FS users value industry expertise at the signing partner and/or audit firm level. 


\section{Literature review and hypothesis development}

It is important to acknowledge that an external FS audit only adds credibility to the FS if FS users estimate the probability of the auditor reporting a breach, to be non-zero (Watts and Zimmerman, 1986). The latter probability depends on the quality of the auditor monitoring the FS. In the literature, it is argued that audit quality is conditional upon both the auditor's competence (i.e. the probability that an auditor discovers a given breach) and the auditor's independence (i.e. the probability that an auditor reports a discovered breach) (e.g., Watts and Zimmerman, 1986). Based on these considerations, large audit firms are assumed to provide audits of a higher quality than small audit firms because they have a greater number of clients and are assumed to be less dependent upon their clients (e.g., DeAngelo, 1981; Watts and Zimmerman, 1986). Empirical studies therefore often distinguish between BigN and nonBigN audit firms (i.e., to proxy for differences in audit quality between large and small audit firms). While various studies in the for-profit sector indicate that BigN auditors provide higher quality audits than their smaller counterparts (e.g., DeFond and Jiambalvo, 1991; Teoh and Wong, 1993; Craswell et al., 1995; Francis et al., 1999), results in the NP and government sector are far less convincing (Tate and Feng, 2013). As an illustration, audits performed by BigN audit firms in the NP (and government) sector are not found to impact the goingconcern decision (Vermeer et al., 2013); are less likely to give rise to the disclosure of internal control weaknesses (Lopez et al., 2013); are not associated with higher levels of perceived audit quality or auditee satisfaction (Samelson et al., 2006); and are related to lower satisfaction and loyalty towards the auditor (Reheul et al., 2013a). A crucial difference between the for-profit and the NP sector is that NPOs do not predominantly select BigN audit firms (Keating et al., 2005; Tate and Feng, 2013). Market shares of $17 \%$ and $15 \%$ for the BigN are reported, respectively in the UK charity sector (Jetty and Beattie, 2012) and the Belgian NP sector (Verbruggen et al., 2015). It is argued that BigN auditors have only a very 
limited interest in auditing NPOs (Samelson et al., 2006) and are merely interested in the largest charities for economic reasons (Crawford et al., 2009). Big N auditors consider NPO audits to be more demanding and time-consuming (because these organizations often lack accounting expertise), riskier and characterized by restricted funding (Crawford et al., 2009). In sum, the BigN variable does not appear to be a valid proxy for audit quality differences in the NP sector.

As mentioned earlier, there are two determinants of audit quality: (1) independence; and (2) competence. While the BigN proxy takes into account the first determinant, it certainly does not fully control for the second. Therefore, various (for-profit) studies (see e.g. O'Keefe et al., 1994; Solomon et al., 1999; Owhoso et al., 2002; Krishnan, 2003; Balsam et al., 2003) rely on auditor industry expertise (i.e., the extent of audit expertise in a specific industry) in an attempt to capture auditor competence. These studies indeed document a positive relationship between an auditor's industry expertise and the effectiveness of the audit engagement (e.g., the detection of FS errors). The scarce NP and public-sector studies in this domain revealed that audit firms (offices) with industry expertise are associated with less GAAS reporting violations (O'Keefe et al., 1994) and less audit quality deficiencies noted in quality control reviews (Deis and Giroux, 1992). Given the distinctive operating structure and regulatory environment of NPOs, the importance of auditor industry expertise is generally acknowledged in the NP literature (see e.g., Tate, 2007; Vermeer et al., 2009; Lopez et al., 2013). As Beattie et al. (2001) and Tate (2007) point out, even in a well-established audit-market, there are significant differences between external auditing in a NP and a for-profit setting that result from dissimilarities in organizational structure, culture, goals, financial concerns, stakeholders and risk. In addition, the extent and complexity of regulation affecting NPOs is high, which increases the risk of breaches against regulation (Verbruggen et al., 2011b). As argued by Tanyi et al. (2010), an effective audit implies a thorough understanding of the client's 
business and processes. As such, an auditor with industry expertise is likely to improve compliance with (complex) industry-specific accounting requirements and industry-specific laws and regulations. This ability of an auditor with industry expertise is very valuable in the Belgian regulatory framework, which is characterized by very heterogeneous subsectorspecific regulations in the NP sector (Christiaens et al., 2008).

Besides actual audit quality, also the perception of audit quality by NP clients is better for industry expert auditors (Lowensohn et al., 2007; Tate and Feng, 2013). In competing for funds from various resource providers, NP managers engage monitoring services to signal that they use resources in a manner that is consistent with the mission of the NPO (Pearson et al., 1998). Because more credible financial reporting ${ }^{2}$ is likely to lead to greater confidence in the NPO, which in turn can lead to willingness by resource providers to sustain or increase funding (Hyndman and McMahon, 2011), we predict a positive relationship between hiring an auditor with industry expertise and future contributions received. Contributions received by Belgian NPOs mainly consist of government grants (e.g., Jegers, 2011; Verbruggen and Christiaens, 2012). Interviews by Verbruggen et al. (2011b) revealed that Belgian subsidizing and supervisory governments scrutinize FS, audit reports and other financial documents to monitor conformity with regulatory and procedural requirements and with performance standards to justify the provision of grants. As argued by Jetty and Beattie (2012), there are greater demands on assurance and deeper scrutiny when a NPO is in receipt of government grants. Unlike unsophisticated small donors, Belgian subsidizing and supervisory governments are professional users of NPOs' FS and better able to evaluate auditors' industry expertise (and thus the signal of hiring an auditor with industry expertise). Thus, we hypothesize:

H1: $\quad$ There is a positive relationship between hiring an auditor with industry expertise and future contributions received by the NPO. 
Although prior for-profit research suggests that industry expertise at the audit partner level is more relevant than at the audit firm level in explaining actual audit quality (Chi and Chin, 2011), we formulate the hypothesis in general form (i.e., in terms of 'auditor' industry expertise, comprising both the audit partner and the audit firm level). Perceived audit quality (our focus) does not necessarily correspond to actual audit quality (the focus of Chi and Chin, 2011). It is hard (or even impossible) to argue that FS users will especially value industry expertise at the audit partner level, certainly given the lack of prior research evidence. However, we will tackle this explorative question in this study by measuring auditor industry expertise at both levels. 


\section{Data collection and research method}

\section{Data collection}

We focus on Belgian NPOs that are externally audited. These NPOs were identified based on auditors' client records that are collected by the Belgian Institute of Certified Public Accountants. Based on these records, we identified NPOs that engaged an external auditor for the accounting years 2006, 2007, and/or 2008. Our sample period starts in 2006 because Belgian NPOs are only required to publicly file their FS from 2006 onwards (see Reheul et al. (2013b) for a detailed discussion). Next to the names of the NPOs, we also collected the unique NPO number and the name of the auditor (both audit firm and signing partner). Based on these unique NPO numbers, we were able to collect all other required information from the Belfirst database $\mathrm{e}^{3}$ or the organizations' actual $\mathrm{FS}^{4}$. Our sample covers contributions received by Belgian NPOs for accounting years 2007 up to 2010. Because our empirical model requires a time lag (cf. section Dependent variable), our independent variables relate to accounting years 2006 up to 2008. Because of the scope of our paper, we focus on the subsample of Belgian NPOs that rely on contributions (i.e., those Belgian NPOs that report a non-zero value for "membership contributions, other contributions, bequests and grants" in the income statement) in year t. This subsample consists of 1,904 NPO-year observations.

\section{Dependent variable}

We define contributions received by an NPO as the aggregate amount of "membership contributions, other contributions, bequests and grants" that Belgian NPOs disclose in their income statement. ${ }^{5}$ As such, contributions received include both donations and government grants and capture the combined reaction of all outside contributions to the organization for which the resource provider does not receive something in return (Harris and Krishnan, 2012). Consistent with prior research (e.g., Harris and Krishnan, 2012; Feng, 2014), we 
consider a time lag between the dependent variable and the independent variables. This time lag is required to ensure that resource providers have the ability to react to the information disclosed. According to Reheul et al. (2014) the average financial reporting lag of Belgian NPOs exceeds 6 months. As a result, on average, only funding decisions in the second half of year $\mathrm{t}+1$ can be based on the FS of year $\mathrm{t}$. In a similar vein, on average, funding decisions in the first half of year $t+2$ will still be based on the FS of year $t$ (because the FS of $t+1$ have not been filed yet). Based on these considerations, we rely on average contributions received in year $\mathrm{t}+1$ and $\mathrm{t}+2$ scaled by total assets of year $\mathrm{t}^{6}$ as the dependent variable (AVDONSUBS/TA).

\section{Independent variables}

\section{Auditor industry expertise}

We consider auditor industry expertise at both the audit firm level (FIRM_EXPERT) as well as the signing partner level (PARTNER_EXPERT). That is, Carcello and Nagy (2004) and Chi and Chin (2009) indicate that audit quality varies both between and within audit firms.

Moreover, Chi and Chin (2011) reveal that industry expertise at the audit partner level is more relevant than at the audit firm level in explaining audit quality. As discussed in Chi and Chin (2011), capturing industry expertise at the audit firm level is based on the assumption that audit firms acquire industry expertise through knowledge sharing. Capturing industry expertise at the audit partner level, on the other hand, is based on the assumption that auditor industry expertise is tied to individual professionals and their deep personal knowledge of clients, and therefore cannot be readily captured and distributed by the audit firm to other audit partners (Chi and Chin, 2011). Based on prior research, we capture industry expertise by measuring the audit partner's/firm's market share in the client's subsector based on the client's total operating revenues (including both sales and contributions) ${ }^{7}$ (e.g., Balsam et al., 2003; Chi and Chin, 2011). Moreover, we also include the interaction term of partner and firm 
expertise (PARTNER X FIRM_EXPERT) to disentangle the combined (potentially synergetic) partner- and firm-level effects, from the separate effects of partner-level and firm-level industry expertise.

\section{Control variables}

Trussel and Parsons (2008) identify four determinants of contributions received by an NPO: (1) available information; (2) efficiency; (3) financial stability; and (4) reputation. Other researchers also include a possible crowding-out effect as a fifth factor (e.g., Weisbrod and Dominguez, 1986; Emanuele and Simmons, 2004). Because Belgian NPOs do not disclose program expenses in their FS, we are not able to include the efficiency variable in our model. As a result, we only control for the other four determinants in our research model: information quantity, financial stability, reputation and crowding-out.

Information quantity. Prior research documents a positive association between the extent of public disclosure and the level of donations received (Parsons, 2003; Trussel and Parsons, 2008; Atan et al., 2012). Belgian NPOs are required to file their FS according to a prescribed format. Two formats exist: a complete format and an abbreviated format. The former is more detailed and has higher information value than the latter. Very large NPOs are obliged to use the complete format, whereas small and large NPOs have the possibility to file the abbreviated format ${ }^{8}$. We control for the format of the FS filed (FORMAT).

Financial stability. The motives of resource providers will only be realized in case of a going concern (Parsons, 2003; Trussel and Parsons, 2008). Just like for for-profit firms, it is important for NPOs to maintain a positive equity in order to ensure future survival (Trussel and Parsons, 2008) and to face economic downturns (Tuckman and Chang, 1991). We therefore include a dummy variable that is coded one if the NPO has a negative equity (and zero otherwise) as a proxy for financial instability (NEGEQ). On the other hand, donors may 
reduce their donations to NPOs who choose to retain (excessive) resources rather than using them for their charitable goals (Maduras, 2004; Calabrese, 2011). As a result, resource providers may presume that NPOs with high levels of (accumulated) profits, cash (equivalents) and/or other operational assets (such as inventories and receivables) are not using contributions in the interest of their mission. We therefore include the current ratio (CURRENT), return on assets (ROA) and retained earnings (or accumulated profits) scaled by total assets $(A C C P R O F)$ in our model.

Reputation. As mentioned earlier, NPOs' resource providers (i.e., donors and governments) are not able to assess directly the quality of the NPO's output. As a result, resource providers will have to rely on the FS and the reputation of the NPO, amongst others, to evaluate its performance. Prior literature relies on age and size as proxies for the reputation of the NPO (e.g. Tinkelman, 2004; Trussel and Parsons, 2008; Kitching, 2009; Feng, 2014). We therefore include the age and the size of the NPO ( $A G E$ and SIZE, respectively), as control variables in our model.

Crowding-out. Crowding-out relates to the fact that resource providers may refrain from contributing if the NPO has a high level of other resources and/or revenues (see e.g., Weisbrod and Dominguez, 1986). Individual donors may perceive high commercial sales revenues as an indication that the mission of the NPO has changed, which may result in a decrease in donations (Enjolras, 2002). We therefore control for a potential crowding-out effect by including the ratio of sales over total assets $(S A L E S / T A)$ in our model.

\section{Research model}

In sum, we run the following mixed effects panel data model: 
$A V D O N S U B S_{i t} / T A_{i t}=\delta_{0}+\delta_{1}$ PARTNER_EXPERT $T_{i t}+\delta_{2}$ FIRM_EXPERT $T_{i t}+\delta_{3}$ PARTNER X

$F I R M \_E X P E R T_{i t}+\delta_{4}$ FORMAT $_{i t}+\delta_{5} N E G E Q_{i t}+\delta_{6} C U R R E N T_{i t}+\delta_{7} R O A_{i t}+\delta_{8}$

$A C C P R O F_{i t}+\delta_{9} A G E_{i t}+\delta_{10} S I Z E_{i t}+\delta_{11} S A L E S_{i t} / T A_{i t}+\varepsilon_{i t}$

where i and t denote organizations and years respectively. Since our model combines both fixed (independent variables at the NPO-level) and random effects (NPO-level within NP sector level), we opt for a mixed effects model (Hamilton, 2012; Seltman, 2014). ${ }^{9}$ Due to considerable differences between subsectors, all financial variables are subsector-adjusted by subtracting the subsector average (see e.g., Verbruggen et al., 2011). ${ }^{10}$ All continuous variables are winsorized at 1 and $99 \%$ by restating the outliers to the largest non-outlying value. Table 1 provides a detailed overview of all variable definitions. 


\section{Results}

Descriptive statistics are presented in Table 2, while the correlation matrix is presented in Table 3. Multicollinearity is not an issue as the correlations between the independent variables fall below .600, and the variance inflation factors (VIFs) well below 2.

Mixed effect panel data results are presented in Table 4. Model I explains future contributions received based on two types of auditor industry expertise (expertise at the signing partner level (PARTNER_EXPERT) and expertise at the audit firm level (FIRM_EXPERT)) and their interaction (PARTNER X FIRM_EXPERT). The explanatory power of the model equals 0.318 (or 31,8\%). Our results indicate that the coefficient for PARTNER_EXPERT is significantly positive (which supports our hypothesis), but that FIRM_EXPERT does not attain statistical significance at the conventional levels. Moreover, the interaction term PARTNER X FIRM_EXPERT is not significant. Our results thus suggest that NPOs' resource providers perceive audit quality at the signing partner level (and not at the audit firm level). This observation is in line with prior empirical evidence that auditor industry expertise is held by individual partners and is not uniformly distributed to other partners within the audit firm (e.g., Carcello and Naggy, 2004; Chi and Chin, 2009). This is especially relevant in the Belgian NP audit market for different reasons. While the market share of NP audits is relatively limited in the overall Belgian audit market $^{11}$, NP audits require a high degree of industry expertise. That is, the legal environment of Belgian NPOs is characterized by much heterogeneity because of various subsector regulations (see e.g., Christiaens et al., 2008) that auditors need to become acquainted with. Moreover, the NP sector is fundamentally different from the for-profit sector, which will have an impact on the audit process and the audit of an NPO thus necessitates other kinds of competences and experiences. Because of the limited market share of NP audits in the overall Belgian audit market, a relatively large portion of audit partners is not active in the NP sector. It therefore appears logical to assume that 
expertise related to the NP sector is not uniformly distributed among partners within audit firms.

With regard to the control variables, the results of Model I in Table 4 indicate that the variables FORMAT, ROA, ACCPROF, AGE, SIZE and SALES/TA attain statistical significance at the conventional levels. The coefficient for information quantity (FORMAT) is positive and significant, which is consistent with prior literature (e.g., Parsons, 2003; Trussel and Parsons, 2008; Atan et al., 2012) indicating that NPOs that file the complete format of the FS, and thus disclose more information, receive more future contributions. Return on assets $(R O A)$ is positively associated with the dependent variable, whereas accumulated profits (ACCPROF) are negatively associated with future contributions received. As argued by Parsons (2003) and Trussel and Parsons (2008), resource providers value the financial stability of an NPO (as indicated by ROA, amongst other). However, they also penalize NPOs with high levels of accumulated profits by reducing future contributions (Maduras, 2004; Calabrese, 2011). In line with the reputation argument, the coefficient for $A G E$ is positive. As a result, older (younger) NPOs will receive more (less) future contributions. Nevertheless, in contrast with our expectations, the coefficient for SIZE is negative, which indicates that large (small) NPOs receive less (more) future contributions. Consistent with prior literature (e.g. Weisbrod and Dominguez, 1986; Enjolras, 2002), the coefficient for SALES/TA is negative. So, consistent with the crowding-out argument, resource providers decrease contributions to NPOs with high commercial revenues.

It has been recognized in the literature that auditors are not randomly chosen. It is likely that NPOs self-select into the group with an industry expert auditor or into the group without, based on a number of determinants, such as organizational size, reliance on donations and grants, leverage, etc.. For example, good NPOs that are well run might be more likely to select an auditor with industry expertise. It is therefore necessary to check whether the 
dependent variable (future contributions) is driven by appointing an auditor with industry expertise, or whether it is driven by the determinants of auditor choice. To control for potential self-selection bias (i.e., self-selection issues may bias the coefficients of our auditor variables), we rely on propensity score matching (PSM). PSM matches the members in the treatment group (i.e., NPOs with an industry expert auditor) to members in the untreated group (i.e., NPOs without an industry expert auditor) based on a propensity score, being an estimated probability of treatment. PSM assigns a propensity score to each NPO in the dataset, using an estimated auditor selection model (probit in our case) that includes the following determinants of auditor choice (based on Tate (2007) and Verbruggen et al. (2014)): DONSUBSTA, SIZE, CURRENT, a measure for leverage (total debt over total assets), a measure of agency problems (wages over total assets) and dummies representing the different NP subsectors and the different years). The propensity score is used as a measure of similarity to match NPOs with industry expert auditor to 'similar' NPOs without. To perform PSM we relied on the nnmatch command in Stata (applying nearest-neighbor matching with replacement, see Abadie et al., 2004). In a next step, the identified matched samples are used to perform regressions that control for potential self-selection. Results based on the matched samples are presented in Table 4 (Model II and Model III). The sample of Model II (Model III) contains NPOs that have been matched on the propensity to appoint an audit partner (audit firm) with industry expertise. ${ }^{12}$ Because Model II (Model III) is aimed at controlling for self-selection and at potentially affecting the coefficient for PARTNER_EXPERT $\left(F I R M \_E X P E R T\right)$ and the interaction term (PARTNER X FIRM_EXPERT) we merely focus on these coefficients in discussing the results of the respective models. The coefficient for PARTNER_EXPERT remains significantly positive in Model II and the coefficient for FIRM_EXPERT does not attain statistical significance in Model III. In both models (II and III) the interaction term PARTNER X FIRM_EXPERT does not attain statistical significance at 
the conventional levels. Consequently, the PSM analyses suggest that the results of Model I are not driven by self-selection bias and that future contributions are driven by industry expertise at the audit partner level, rather than industry expertise at the audit firm level.

\section{Additional analyses}

As discussed earlier, prior studies often use the Big4 dummy variable as a proxy for differences in audit quality. We therefore also included the Big4 dummy in our model. The dummy variable is coded one if the auditor belongs to a Big4 audit firm; and zero otherwise. Results indicate that the Big4 variable is positively associated with future contributions, but only at the 10 percent significance level. Importantly, when including the Big4 dummy variable, the coefficient for PARTNER_EXPERT remains significantly positive (and the coefficients for FIRM_EXPERT and PARTNER X FIRM_EXPERT remain statistically insignificant at the conventional levels).

Next, we ran the analyses separately for the two largest NP subsectors, being research and education $(n=553)$ and social services $(n=908)$. Importantly, both NP subsectors differ in terms of the way they are financed. That is, while NPOs in research and education rely far more heavily on grants, NPOs in social services rely more heavily on donations. ${ }^{13}$ Interestingly, the coefficient for PARTNER_EXPERT only attains statistical significance based on the sub-sample of NPOs in research and education (and not based on the sub-sample of NPOs in social services). As such, this finding is consistent with our expectations. As argued before, unlike small donors, governments are professional users of NPOs' FS and are therefore likely to correctly assess auditors' industry expertise (and thus the signal of hiring an auditor with industry expertise). The observation that auditor industry expertise only 
matters in the subsector that relies much more heavily on grants is consistent with our argument. 


\section{Summary and conclusion}

Given NPOs' strong reliance on government grants, donations and volunteers, it is important to safeguard the quality of their financial reporting and to consider the monitoring role provided by the external auditor. In the current paper, we add to the literature by assessing the impact of auditor choice in favor of an industry expert auditor on future contributions received (i.e., the sum of donations and grants received) among a large sample of Belgian NPOs. Consistent with a signaling perspective, our results indicate that NPOs benefit from engaging an audit partner with industry expertise. Specifically, we observe a significantly positive relationship between industry expertise of the signing partner and future contributions received by the NPO. Nevertheless, we find no significant impact of auditor industry expertise at the audit firm level. While prior nonprofit studies on economic consequences of auditor choice only considered the audit firm level (Kitching, 2009; Harris and Krishnan, 2012), our study considers both audit firm- and partner-level industry expertise (as well as their interaction) and as such makes an important contribution to the literature. Further, we extend the for-profit study of Chi and Chin (2011) who also revealed the supremacy of partner-level over firm-level industry expertise, but who studied actual audit quality (by considering financial reporting consequences of auditor choice, being the effect on discretionary accruals and the likelihood of issuing a modified audit opinion), whereas we study perceived audit quality (by considering economic consequences of auditor choice, being the effect on future contributions received). Our findings are relevant for NPOs' managers and stakeholders as they reveal the importance of auditor choice in favor of an auditor with industry expertise in a NP setting. In addition, findings are relevant for regulators as well, as they indicate the relevance of disclosing the signing audit partner's name (which is mandatory in Belgium, but not in the US, for example). 
Because of data limitations, we assess the effect of auditor choice on aggregate contributions. This certainly is a limitation of the current study. Because contributions mainly consist of government grants in the Belgian setting (e.g., Jegers, 2011; Verbruggen and Christiaens, 2012) we conclude that future government grants received are affected by auditor industry expertise (at the signing partner level). It would certainly be relevant for further research to examine whether auditor choice affects both types of resource providers (i.e., governments and donors) in the same way. That is, unlike governments, (small) donors will typically not be professional users of NPOs' FS and they are therefore less likely to be able to correctly assess auditors' industry expertise (and thus the signal of hiring an auditor with industry expertise). While our additional analyses based on two subsectors already provide some insights in that respect, future research is encouraged to assess the generalizability of our findings to other settings (e.g., a setting where contributions are mainly received from private donors). 


\section{Endnotes}

1. In Belgium, the name of the audit firm and the signing partner are publicly disclosed in the FS (i.e., in the audit report).

2. As argued by Carrey et al. (2013), the impact of an auditor does not need to be restricted to higher FS quality, but could also result in increased professionalism of management, which might then influence the culture, governance and quality of management of the firm. That is, the auditor may transfer knowledge from other clients (e.g., best practices in internal control and/or corporate governance) to a client that would otherwise not be available within the organization. In addition, the industry expertise of an auditor may allow him or her to better identify potential compliance risks that the client might have been unaware of (Carrey et al., 2013).

3. Bureau van Dijk's Belfirst database contains FS data for Belgian NPOs and forprofits.

4. A limitation of the Belfirst database is that it only includes data from FS that have been filed according to a format prescribed by law (because information in the Belfirst database is presented according to these templates). Nevertheless, certain subsectors prescribe alternative formats and data with respect to NPOs that file their FS employing an alternative format is therefore not available in the Belfirst database. For NPOs using an alternative format, we manually collected the required information from the actual FS. Belgian companies (including NPOs) that have to prepare FS, need to file these FS (including the audit report) with the National Bank of Belgium (NBB). These FS are then made available to the general public through the website of the NBB and we therefore used this website to collect the actual FS.

5. While NPOs are required to split up this aggregate figure in the notes to their FS, the note regarding this item is characterized by a lot of inaccuracies and we therefore rely 
on the aggregate figure. Specifically, for about $44 \%$ of our observations, the detail provided in the notes to the FS does not add up to the figure disclosed in the income statement. To assess the validity of our auditor industry proxies, we created a FS quality dummy variable that is coded one if the detail provided in the notes to the FS adds up to the figure disclosed in the income statement; and zero otherwise. Next, we checked the correlation between our auditor industry expertise proxies and this FS quality dummy variable. Consistent with auditor industry expertise resulting in higher audit quality, we observe a significantly positive (at the $1 \%$ level) correlation between both FIRM_EXPERT and PARTNER_EXPERT and the aforementioned dummy variable. In line with Chi and Chin (2011), the correlation coefficient for PARTNER_EXPERT is much larger than the correlation coefficient for FIRM_EXPERT (i.e., 0.1964 vs. 0.0992, respectively). This observation confirms that industry expertise at the audit partner level is more relevant than at the audit firm level in explaining audit quality. Interestingly, the correlation coefficient between the traditional Big4 variable and the FS quality dummy variable does not attain statistical significance. This observation confirms that the BigN variable does not appear to be a valid proxy for audit quality differences in the NP sector.

6. Note that for scaling the dependent variable, we use total assets for year t to make sure that our model only captures changes in the amount of contributions received and not changes in total assets.

7. The following (NPO) subsectors are discerned: (1) culture, sports and recreation; (2) education and research; (3) healthcare; (4) social service; (5) advocacy; and (6) other. Because industry expertise is determined based on clients' total operating revenues, we consider all NPOs to determine market shares (i.e., we do not restrict us to the 
subsample of NPOs that report a non-zero value for "membership contributions, other contributions, bequests and grants") for these purposes.

While it is rather common to capture auditor industry expertise based on auditors' market share (see e.g., Ferguson et al., 2003; Reichelt and Wang, 2010), prior studies have also considered auditor industry expertise based on number of audit clients in the industry (see e.g., Tate, 2007). As an alternative proxy for auditor industry expertise, we therefore also considered the natural logarithm of the number of clients of the auditor within a specific subsector. Employing this alternative proxy, our results do not hold. Importantly, auditor industry expertise measured based on number of clients within the subsector ignores the magnitude of the subsector (i.e., an auditor dominating a small subsector might still have a relatively small number of clients in that specific subsector). Because the size of subsectors differs considerably for our sample (i.e., sector 3 (healthcare), for example, has 57 observations over the sample period, while sector 4 (social service) has 908 observations over the sample period), a proxy based on number of audit clients does not really appear appropriate.

8. In a Belgian setting, an NPO is considered to be very large if: (a) it has more than 100 employees (yearly average) or (b) if at least two of the following criteria are met: (1) more than 50 employees (yearly average); (2) total incoming resources amount to at least 7300000 EUR (excluding value-added tax); (3) total assets of at least 3650000 EUR.

9. Similar to fixed and random effect panel data, "fixed effects have levels that are of primary interest and would be used again if the experiment were repeated. Random effects have levels that are not of primary interest, but rather are thought of as a random selection from a much larger set of levels" (Seltman, 2014: 358). 
10. Analyses with non-subsector-adjusted financial variables generate similar research findings.

11. In Belgium, all organizations (both for-profits and NPOs) that are required to file the complete format of the FS are subject to a mandatory external FS audit. For accounting year 2013, for example, 23,406 for-profits filed the complete format of the FS, whereas only 1,396 NPOs filed the complete format of the FS. Based on this rough information (e.g., ignoring client size, organizations voluntarily filing the complete format of the FS), NPOs account for about six percent of the Belgian audit market (i.e., in terms of number of clients).

12. In order to distinguish between auditors with industry expertise and those lacking industry expertise in the PSM analysis, we create dummy variables at both the signing partner and audit firm level, that are coded one if the auditor has a higher market share than the average auditor does in a particular subsector. This approach is based on Verbruggen et al. (2014).

13. Based on NPOs for which detail in the notes regarding revenues adds up to the figure in the income statement (cf. endnote 5), grants account for, on average, 151\% (62.29\%) of total assets for NPOs in research and education (social service), while donations account for $2.12 \%(4.72 \%)$ of total assets. 


\section{References}

Abadie, A., Drukker, D., Herr, J.L., \& Imbens, G.W. (2004). Implementing matching estimators for average treatment effects in Stata. Stata Journal, 4, 290-311.

Abraham, A. (1999). Financial accountability in nonprofit organisations: Voluntary audit as self-regulation, Third Sector Review, 5, 25-40.

Amin, K., \& Harris, E.E. (2015). Nonprofit Stakeholder Response to Going-Concern Audit Opinions, Journal of Accounting, Auditing \& Finance, DOI: 10.1177/0148558X15604989, pp. 1-21.

Atan, R., Zainon, S., \& Wah, Y.B. (2012). Quality information by charity organizations and its relationship with donations. In Jha, M.K., Lazard, M., Zaharim, A., \& Sopian, K. (Eds.), Recent advances in business administration. Cambridge: Harvard.

Balsam, S., Krishnan, J., \& Yang, J.S. (2003). Auditor industry specialization and earnings quality. Auditing: A Journal of Practice \& Theory, 22, 71-97.

Beattie, V., Goodacre, A., Pratt, K., \& Stevenson, J. (2001). The determinants of audit fees evidence from the voluntary sector. Accounting and Business Research, 31, 243-274.

Burks, J.J. (2015). Accounting errors in nonprofit organizations. Accounting Horizons, 29, 341-361.

Calabrese, T.D. (2011). Do donors penalize nonprofit organizations with accumulated wealth? Public Administration Review, 71, 859-869.

Carcello, J., \& Nagy, A. (2004). Client size, auditor specialization, and fraudulent financial reporting. Managerial Auditing Journal, 19, 651-668. 
Carey, P., Knechel, W.R., \& Tanewski, G. (2013). Costs and Benefits of Mandatory Auditing of For-profit Private and Not-for-profit Companies in Australia. Australian Accounting Review, 64, 43-53.

Chi, H-Y., \& Chin, C-L. (2009). Reducing restatements with increased industry expertise. Contemporary Accounting Research, 26, 729-765.

Christiaens, J., Vanhee, C., Verbruggen, S., \& Milis, K. (2008). Verenigingen en stichtingen: Vergelijkend en empirisch onderzoek van de boekhoudregelingen [Associations and foundations: Comparative and empirical examination of the accounting rules]. Bruges, Belgium: Die Keure.

Craswell, A.T., Francis, J.R., \& Taylor, S.L. (1995). Auditor brand name reputations and industry specializations. Journal of Accounting and Economics, 20, 297-322.

Crawford, L., Dunne, T., Hannah, G., \& Stevenson, L. (2009). An exploration of Scottish charities' governance and accountability. Edinburgh: The Institute of Chartered Accountants of Scotland.

Datar, S., Feltham, G., \& Hughes, J. (1991). The role of audits and audit quality in valuing new issues. Journal of Accounting and Economics, 14, 3-49.

DeAngelo, L. (1981). Auditor size and audit quality, Journal of Accounting and Economics, 3, 183-199.

DeFond, M.L., \& Jiambalvo, J. (1991). Incidence and circumstances of accounting errors. The Accounting Review, 66, 643-655. 
Deis, D.R., \& Giroux, G.A. (1992). Determinants of audit quality in the public sector. The Accounting Review, 67, 462-479.

Eldenburg, L.G., Gunny, K.A., Hee, K.W., \& Soderstrom, N. (2011). Earnings management using real activities: evidence from nonprofit hospitals. The Accounting Review, 86, $1605-1630$.

Emanuele, R., \& Simmons, W. (2004). Does government spending crowd out donations of time and money? Public Finance Review, 32, 498-511.

Enjolras, B. (2002). The Commercialization of voluntary sport organizations in Norway, Nonprofit and Voluntary Sector Quarterly, 31, 352-376.

Feng, N.C. (2014). Economic Consequences of Going Concern Audit Opinions in Nonprofit Charitable Organizations, Journal of Governmental \& Nonprofit Accounting, 3, 20-34.

Ferguson, A., Francis, J.R., \& Stokes, D.J. (2003). The effects of firm-wide and office-level industry expertise on audit pricing. The Accounting Review, 78, 429-448.

Francis, J.R., Maydew, E.L., \& Sparks, H.C. (1999). The role of Big 6 auditors in the credible reporting of accruals. Auditing: A Journal of Practice \& Theory, 18, 17-34.

Greenlee, J.S., \& Brown, K.L. (1999). The impact of accounting information on contributions to charitable organizations. Research in Accounting Regulation, 13, 111-125.

Haggar-Guenette, C., Hamdad, M., Laronde-Jones, D., Pan, T., \& Yu, M. (2009). The Satellite Account of Nonprofit Institutions and Volunteering. Statistics Canada, Catalogue no. 13-015-X58.

Hamilton, L.C. (2012). Statistics with stata. Boston, USA: Cengage. 
Hansmann, H. (1987). Economic theories of nonprofit organizations. In Walker, P. (Ed.), Accountability in urban society: a research handbook. New Haven, CT: Yale University Press.

Harris, E.E., \& Krishnan, J. (2012). The impact of tarnished auditor reputation on nonprofit income. International Journal of Auditing, 16, 130-145.

Harris, E., Petrovits, M., \& Yetman, M.H. (2015). The effect of nonprofit governance on donations: evidence from the revised form 990. The Accounting Review, 90, 579-610.

Hyndman, N., \& McMahon, D. (2011). The hand of government in shaping accounting and reporting in the UK charity sector. Public Money \& Management, 31, 167-174.

Jegers, M. (2011). On the capital structure of non-profit organisations: A replication and extension with Belgian data. Financial Accountability \& Management, 27, 18-31.

Jegers, M. (2013). Do nonprofit organizations manage earnings? An empirical study. Voluntas, 24, 953-968.

Jetty, J., \& Beattie, V. (2012). The determinants of audit committees: evidence from the charity sector. Public Money \& Management, 32, 371-378.

Jones, C.L., \& Roberts, A.A. (2006). Management of financial information in charitable organizations: the case of joint-cost allocations. The Accounting Review, 81, 159-178.

Keating, E.K., Fischer, M., Gordon, T.P., \& Greenlee, J. (2005). The single audit act: How compliant are nonprofit organizations? Journal of Public Budgeting, Accounting \& Financial Management, 17, 285-309. 
Keating, E.K., Parsons, L.M., \& Roberts, A.A. (2008). Misreporting fundraising: how do nonprofit organizations account for telemarketing campaigns? The Accounting Review, $83,417-446$.

Kitching, K. (2009). Audit value and charitable organizations, Journal of Accounting and Public Policy, 28, 510-524.

Krishnan, G.V. (2003). Audit quality and the pricing of discretionary accruals. Auditing: A Journal of Practice \& Theory, 22, 109-126.

Krishnan, R., Yetman, M., \& Yetman, R. (2006). Expense misreporting in nonprofit organizations. Accounting Review, 81, 399-420.

Leone, A.J., \& Van Horn, R.L. (2005). How do nonprofit hospitals manage earnings? Journal of Health Economics, 24, 815-837.

Lopez, D.M., Rich, K.T., \& Smith, P.C. (2013). Auditor size and internal control reporting differences in nonprofit healthcare organizations. Journal of Public Budgeting, Accounting \& Financial Management, 25, 41-68.

Lowensohn, S., Johnson, L.E., Elder, R.J., \& Davies, S.P. (2007). Auditor specialization, perceived audit quality, and audit fees in the local government audit market. Journal of Accounting and Public Policy, 26, 705-732.

Maduras, N.P. (2004). Effects of nonprofit organization wealth and efficiency on private donations to large nonprofit organizations. Research in Government and Nonprofit Accounting, 11, 71-91. 
O’Keefe, T.B., King, R.D., \& Gaver, K.M. (1994). Audit fees, industry specialization and compliance with GAAS reporting standards, Auditing: A journal of Practice and Theory, $13,41-55$.

Owhoso, E.V., Messier, W.F., \& Lynch, J.G. (2002). Error detection by industry-specialized teams during sequential audit review. Journal of Accounting Research, 40, 883-900.

Parsons, L.M. (2003). Is accounting information form nonprofit organizations useful to donors? A review of charitable giving and value-relevance, Journal of Accounting Literature, 22, 104-129.

Pearson, T.A., Brooks, R.C., \& Neidermeyer, A.A. (1998). The determinants of monitoring costs in non-profit organizations. Journal of Public Budgeting, Accounting \& Financial Management, 10, 499-512.

Pettijohn, S.L., Boris, E.T., De Vita, C.J., \& Fyffe, S.D. (2013). Nonprofit-Government Contracts and Grants: Findings from the 2013 National Survey. The Urban Institute. 53 p.

Petrovits, C., Shakespeare, C., \& Shih, A. (2011). The causes and consequences of internal control problems in nonprofit organizations. The Accounting Review, 86, 325-357.

Privett, N., \& Erhun, F. (2011). Efficient Funding: Auditing in the Nonprofit Sector. Manufacturing \& Service Operations Management, 13, 471-488.

Reheul, A.-M., Van Caneghem, T., \& Verbruggen, S. (2013a). Auditor Performance, Client Satisfaction and Client Loyalty: Evidence from Belgian Non-Profits. International Journal of Auditing, 17, 19-37. 
Reheul, A., Van Caneghem, T., \& Verbruggen, S. (2013b). Audit report lags in the Belgian non-profit sector: An empirical analysis. Accounting and Business Research, 43, 138158.

Reheul. A, Van Caneghem, T., \& Verbruggen S. (2014). Financial reporting lags in the nonprofit sector: an empirical analysis, Voluntas, 25, 352-377.

Reheul, A.-M., Van Caneghem, T., \& Verbruggen, S. (2015). Nonprofit organizations' choice in favor of a sector expert auditor: A study of behavioral choice criteria. Journal of Public Budgeting, Accounting \& Financial Management, 27, 179-224.

Reichelt, J. K., \& Wang, D. (2010). National and office-specific measures of auditor industry expertise and effects on audit quality. Journal of Accounting Research, 48, 647-686.

Samelson, D., Lowensohn, S., \& Johnson, L.E. (2006). The determinants of perceived audit quality and auditee satisfaction in local government. Journal of Public Budgeting, Accounting \& Financial Management, 18, 139-166.

Seltman, H.J. (2015). Experimental design and analysis. Carnegie Mellon University. Online only: http://www.stat.cmu.edu/ hseltman/309/Book/Book.pdf

Solomon, I., Shields, M.D., \& Whittington, O.R. (1999). What do industry-specialist auditors know? Journal of Accounting Research, 37, 191-208.

Tanyi, P., Raghunandan, K., \& Barua, A. (2010). Audit report lags after voluntary and involuntary auditor changes. Accounting Horizons, 671-688.

Tate, S. (2007). Auditor change and auditor choice in nonprofit organizations. Auditing: A Journal of Practice \& Theory, 26, 47-70. 
Tate, S., \& Feng, N.C. (2013). Perceived Quality Auditors in the Nonprofit Sector: Evidence from Request for Proposal Choices. Mustang Journal of Accounting \& Finance, 4, 6596.Teoh, S.H., \& Wong, T.J. (1993). Perceived auditor quality and the earnings response coefficient. The Accounting Review, 68, 346-366.

Thornton, J., \& Belski, W. (2010). Financial reporting quality and price competition among nonprofit firms. Applied Economics, 42, 2699-2713.

Tinkelman, D. (2004). Using nonprofit organization-level financial data to infer managers' fund-raising strategies. Journal of Public Economics, 88, 2181-2192.

Titman, S., \& Trueman, B. (1986). Information quality and the valuation of new issues. Journal of Accounting and Economics, 8, 159-172.

Torres, L., \& Pina, V. (2003). Accounting for accountability and management in NPOs. A comparative study for four countries: Canada, the United Kingdom, the USA and Spain. Financial Accountability and Management, 19, 265-285.

Trussel, J.M., \& Parsons, L.M. (2008). Financial reporting factors affecting donations to charitable organizations, Advances in Accounting, 23, 263-285.

Tuckman, H.P., \& Chang, C.F. (1991). A methodology for measuring the financial vulnerability of charitable nonprofit organizations. Nonprofit and Voluntary Sector Quarterly, 20, 445-460.

Verbruggen, S., Christiaens, J., \& Milis, K. (2011a). Can resource dependence and coercive isomorphism explain nonprofit organizations' compliance with reporting standards? Nonprofit and Voluntary Sector Quarterly, 40, 5-32. 
Verbruggen, S., Reheul, A.-M., Van Caneghem, T., Dierick, J., Christiaens, J., \& Vanhee, C. (2011b). Het bedrijfsrevisoraat in de verenigingssector/Le révisorat d'entreprises dans le secteur associatif. Antwerpen/Apeldoorn: ICCI \& Maklu. [External auditing in the nonprofit sector.]

Verbruggen, S., \& Christiaens, J. (2012). Do non-profit organizations manage earnings toward zero profit and does governmental financing play a role? Canadian Journal of Administrative Sciences, 29, 205-217.

Verbruggen, S., Christiaens, J., Reheul, A., \& Van Caneghem, T. (2015). Analysis of audit fees for nonprofits: Resource dependence and agency theory approaches. Nonprofit and Voluntary Sector Quarterly, 44, 734-754.

Vermeer, T.E., Raghunandan, K., \& Forgione, D.A. (2009). Audit fees at U.S. non-profit organizations. Auditing: A Journal of Practice \& Theory, 28, 289-303.

Vermeer, T.E., Raghunandan, K., \& Forgione, D.A. (2013). Going-concern modified audit opinions for non-profit organizations. Journal of Public Budgeting, Accounting \& Financial Management, 25, 113-134.

Vermeer, T.E., Edmonds, C.T., \& Asthana, S.C. (2014). Organizational form and accounting choice: are nonprofit or for-profit managers more aggressive? The Accounting Review, 89, 1867-1893.

Watts, R. L., \& Zimmerman, J. L. (1986). Positive accounting theory. Englewood Cliffs: Prentice-Hall. 
Weisbrod, B.A., \& Dominguez, N.D. (1986). Demand for collective goods in private nonprofit markets: can fundraising expenditures help overcome free-rider behavior? Journal of Public Economy, 30, 83-96.

Wren, T. (2009). Study into the Contribution of the Not for Profit Sector. Australian Council of Social Service (ACOSS), $50 \mathrm{p}$.

Yetman, M.H., \& Yetman, R.J. (2013). Do donors discount low-quality accounting information? Accounting Review, 88, 1041-1067. 
TABLE 1: Variable definitions

\begin{tabular}{|c|c|c|}
\hline Variable Name & Variable description & $\begin{array}{c}\text { Expected } \\
\text { sign }\end{array}$ \\
\hline AVDONSUBS/TA & $\begin{array}{l}\text { Average total contributions measured as average contributions } \\
\text { received in year } t+1 \text { and } t+2 \text { over total assets of year } t \text {. }\end{array}$ & Dependent \\
\hline PARTNER_EXPERT & $\begin{array}{l}\text { Industry expertise at the signing partner level measured as } \\
\text { the market share of the signing partner in the client's subsector based } \\
\text { on clients' total (operating) revenues. }\end{array}$ & + \\
\hline FIRM_EXPERT & $\begin{array}{l}\text { Industry expertise at the audit firm level measured as the market } \\
\text { share of the audit firm in the client's subsector based on clients' total } \\
\text { (operating) revenues. }\end{array}$ & + \\
\hline PARTNER X & The interaction term of PARTNER_EXPERT and FIRM_EXPERT. & + \\
\hline \multicolumn{3}{|l|}{ FIRM_EXPERT } \\
\hline FORMAT & $\begin{array}{l}\text { Dummy variable that is coded } 1 \text { if the NPO files the complete format } \\
\text { of the FS; and } 0 \text { otherwise. }\end{array}$ & + \\
\hline$N E G E Q$ & $\begin{array}{l}\text { Dummy variable that is coded } 1 \text { if the NPO has a negative equity; } \\
\text { and } 0 \text { otherwise. }\end{array}$ & - \\
\hline CURRENT & Current ratio (current assets divided by current liabilities). & - \\
\hline$R O A$ & Return on assets (net income divided by total assets). & + \\
\hline ACCPROF & $\begin{array}{l}\text { The sum of retained earnings and profit for the year divided by total } \\
\text { assets. }\end{array}$ & - \\
\hline$A G E$ & $\begin{array}{l}\text { Natural logarithm of number of years since the incorporation of the } \\
\text { organization. }\end{array}$ & + \\
\hline SIZE & Natural logarithm of total assets. & + \\
\hline SALES/TA & Sales divided by total assets. & - \\
\hline
\end{tabular}


TABLE 2: Descriptive statistics

\begin{tabular}{lccccccc}
\hline Variable & Mean & Min & Max & St.Dev. & $\begin{array}{c}\mathbf{2 5}^{\text {th }} \\
\text { percentile }\end{array}$ & Median & $\begin{array}{c}\mathbf{7 5}^{\text {th }} \\
\text { percentile }\end{array}$ \\
\hline AVDONSUBS/TA & 1.1257 & 0 & 6.3097 & 1.313 & .1561 & .6361 & 1.632 \\
PARTNER_EXPERT & .0167 & .0001 & .0828 & .0190 & .0036 & .0091 & .0223 \\
FIRM_EXPERT & .0315 & .0001 & .4608 & .0550 & .0052 & .0144 & .0374 \\
FORMAT & .7585 & 0 & 1 & & & & \\
CURRENT & 4.6992 & 0 & 109.6284 & 9.8596 & 1.4057 & 2.3639 & 4.5211 \\
ROA & .0264 & -.2351 & .3016 & .0707 & 0 & .0207 & .0541 \\
ACCPROF & .2343 & -.6856 & .8873 & .2807 & .0492 & .1887 & .3957 \\
NEGEQ & .0359 & 0 & 1 & & & & \\
AGE & 3.2797 & 1.0986 & 4.4543 & .6686 & 2.8904 & 3.3673 & 3.7377 \\
SIZE & 8.3638 & 4.9020 & 12.2672 & 1.3278 & 7.5187 & 8.4670 & 9.1783 \\
SALES/TA & .3788 & 0 & 4.1010 & .5654 & .0488 & .1809 & .5032 \\
\hline Variables are defined in Table 1. To facilitate interpretation, reported figures are not subsector-adjusted. & & &
\end{tabular}


TABLE 3: Correlation matrix

\begin{tabular}{|c|c|c|c|c|c|c|c|c|c|c|c|}
\hline & (1) & (2) & (3) & (4) & (5) & (6) & (7) & $(8)$ & (9) & $(10)$ & (11) \\
\hline AVDONSUBS/TA (1) & 1.000 & .031 & $\begin{array}{l}.092 \\
* *\end{array}$ & $\begin{array}{c}-.113 \\
* *\end{array}$ & $\begin{array}{c}-.107 \\
* *\end{array}$ & -.027 & $\begin{array}{c}.101 \\
* *\end{array}$ & $\begin{array}{c}.090 \\
* *\end{array}$ & $\begin{array}{c}-.523 \\
* *\end{array}$ & $\begin{array}{c}-.066 \\
* *\end{array}$ & -.011 \\
\hline PARTNER_EXPERT(2) & & 1.000 & $\begin{array}{l}.536 \\
* *\end{array}$ & $\begin{array}{c}.251 \\
* *\end{array}$ & -.026 & -.026 & .003 & $\begin{array}{c}-.065 \\
* *\end{array}$ & $\begin{array}{l}.218 \\
* *\end{array}$ & $\begin{array}{c}.072 \\
* *\end{array}$ & $\begin{array}{c}.054 \\
*\end{array}$ \\
\hline FIRM_EXPERT (3) & & & 1.000 & $\begin{array}{c}.171 \\
* *\end{array}$ & $\begin{array}{c}-.096 \\
* *\end{array}$ & $\begin{array}{c}-.045 \\
*\end{array}$ & -.018 & $\begin{array}{c}-.068 \\
* *\end{array}$ & $\begin{array}{l}.169 \\
* *\end{array}$ & $\begin{array}{c}.073 \\
* *\end{array}$ & $\begin{array}{c}.124 \\
* *\end{array}$ \\
\hline FORMAT (4) & & & & 1.000 & $\begin{array}{c}-.092 \\
* *\end{array}$ & $\begin{array}{c}-.058 \\
* *\end{array}$ & -.025 & $\begin{array}{c}-.096 \\
* *\end{array}$ & $\begin{array}{c}.511 \\
* *\end{array}$ & $\begin{array}{c}.207 \\
* *\end{array}$ & -.039 \\
\hline CURRENT (5) & & & & & 1.000 & $\begin{array}{c}.165 \\
* *\end{array}$ & .001 & $\begin{array}{c}-.060 \\
* *\end{array}$ & $\begin{array}{c}.176 \\
* *\end{array}$ & $\begin{array}{c}.066 \\
* *\end{array}$ & $\begin{array}{c}-.071 \\
* *\end{array}$ \\
\hline ACCPROF (6) & & & & & & 1.000 & $\begin{array}{l}.238 \\
* *\end{array}$ & $\begin{array}{c}-.359 \\
* *\end{array}$ & .032 & .033 & $\begin{array}{c}-.112 \\
* *\end{array}$ \\
\hline ROA (7) & & & & & & & 1.000 & $\begin{array}{c}-.110 \\
* *\end{array}$ & $\begin{array}{c}-.095 \\
* *\end{array}$ & $\begin{array}{c}-.086 \\
* *\end{array}$ & .038 \\
\hline$N E G E Q(8)$ & & & & & & & & 1.000 & $\begin{array}{c}-.168 \\
* *\end{array}$ & $\begin{array}{c}-.108 \\
* *\end{array}$ & $\begin{array}{c}.160 \\
* *\end{array}$ \\
\hline SIZE (9) & & & & & & & & & 1.000 & $\begin{array}{c}.278 \\
* *\end{array}$ & $\begin{array}{c}-.188 \\
* *\end{array}$ \\
\hline$A G E(10)$ & & & & & & & & & & 1.000 & $\begin{array}{c}-.123 \\
* *\end{array}$ \\
\hline SALES/TA (11) & & & & & & & & & & & 1.000 \\
\hline
\end{tabular}


TABLE 4: Regression results

\begin{tabular}{|c|c|c|c|c|c|c|c|}
\hline \multirow{2}{*}{$\begin{array}{l}\text { Variable name } \\
\text { Constant }\end{array}$} & \multirow[t]{2}{*}{$\begin{array}{l}\text { Predicted } \\
\text { sign }\end{array}$} & \multicolumn{2}{|c|}{$\begin{array}{c}\text { Model I } \\
\text { Full sample }\end{array}$} & \multicolumn{2}{|c|}{$\begin{array}{c}\text { Model II } \\
\text { PSM partner } \\
\text { level }\end{array}$} & \multicolumn{2}{|c|}{$\begin{array}{l}\text { Model III } \\
\text { PSM firm } \\
\text { level }\end{array}$} \\
\hline & & $\begin{array}{l}-.3615 \\
(.061)\end{array}$ & $* *$ & $\begin{array}{r}-.2233 \\
(.071)\end{array}$ & $* *$ & $\begin{array}{r}-.3384 \\
(.071)\end{array}$ & $* *$ \\
\hline PARTNER_EXPERT & + & $\begin{array}{l}5.5280 \\
(1.546)\end{array}$ & $* *$ & $\begin{array}{r}8.0153 \\
(1.964)\end{array}$ & $* *$ & $\begin{array}{l}6.5033 \\
(2.065)\end{array}$ & $* *$ \\
\hline FIRM_EXPERT & + & $\begin{array}{l}.2099 \\
(.549)\end{array}$ & & $\begin{array}{l}.3128 \\
(.670)\end{array}$ & & $\begin{array}{l}.1018 \\
(.733)\end{array}$ & \\
\hline $\begin{array}{l}\text { PARTNER X FIRM_ } \\
\text { EXPERT }\end{array}$ & + & $\begin{array}{r}-17.8785 \\
(11.430)\end{array}$ & & $\begin{array}{r}-28.2873 \\
(20.742)\end{array}$ & & $\begin{array}{r}-17.9254 \\
(12.776)\end{array}$ & \\
\hline FORMAT & + & $\begin{array}{r}.4618 \\
(.064)\end{array}$ & $* *$ & $\begin{array}{l}.2929 \\
(.077)\end{array}$ & $* *$ & $\begin{array}{l}.4448 \\
(.076)\end{array}$ & $* *$ \\
\hline NEGEQ & - & $\begin{array}{l}.1385 \\
(.082)\end{array}$ & & $\begin{array}{l}.1984 \\
(.122)\end{array}$ & & $\begin{array}{l}-.1945 \\
(.206)\end{array}$ & \\
\hline CURRENT & - & $\begin{array}{l}.0015 \\
(.001)\end{array}$ & & $\begin{array}{l}.0005 \\
(.003)\end{array}$ & & $\begin{array}{l}.0024 \\
(.002)\end{array}$ & \\
\hline$R O A$ & + & $\begin{array}{l}.3992 \\
(.131)\end{array}$ & $* *$ & $\begin{array}{r}-.2479 \\
(.197)\end{array}$ & & $\begin{array}{l}.1091 \\
(.219)\end{array}$ & \\
\hline$A C C P R O F$ & - & $\begin{array}{r}-.2271 \\
(.085)\end{array}$ & $* *$ & $\begin{array}{r}-.0393 \\
(.101)\end{array}$ & & $\begin{array}{l}-.0257 \\
(.116)\end{array}$ & \\
\hline$A G E$ & + & $\begin{array}{l}.3074 \\
(.051)\end{array}$ & $* *$ & $\begin{array}{l}.1734 \\
(.056)\end{array}$ & $* *$ & $\begin{array}{l}.1891 \\
(.058)\end{array}$ & $* *$ \\
\hline SIZE & + & $\begin{array}{r}-.7919 \\
(.025)\end{array}$ & $* *$ & $\begin{array}{r}-.6430 \\
(.031)\end{array}$ & $* *$ & $\begin{array}{r}-.7336 \\
(.032)\end{array}$ & $* *$ \\
\hline SALES/TA & - & $\begin{array}{r}-.0797 \\
(.040)\end{array}$ & $*$ & $\begin{array}{r}-.0302 \\
(.057)\end{array}$ & & $\begin{array}{r}-.2660 \\
(.078)\end{array}$ & $* *$ \\
\hline $\mathrm{R}^{2}$ & & .3179 & & .3508 & & .3260 & \\
\hline \# observations & & 1904 & & 985 & & 983 & \\
\hline
\end{tabular}

